\title{
SHARED HISTORIES, PERSONALITIES, TRADITIONS. EUROPEAN EXAMPLES
}

\begin{abstract}
The purpose of this paper is to show the role of the common past in the emergence and development of some smaller European nations. Shared past in the Balkans is seen solely through the prism of nationalism. When someone talks about a shared history, he does it in order to show that the others in that history have no past. There are several examples of shared history worldwide and it is normally not a problem, except in our region. Also, the role of a person in the past of two or more nations is very common and it should not be a ground for misunderstanding and conflict. Fluidity of ethnic identity is not associated only with the Balkans; it is also present in some other European countries. Such is the case, for example, with Lithuania. In addition, when it comes to the role of reformers and intellectuals who had different ethnic backgrounds in the emergence and development of some modern European nations, we may observe that there are such examples, for instance, in Finland and Estonia. Unlike the Balkans, shared histories, common personalities and intellectuals who had different ethnic backgrounds in terms of nations where they contributed greatly, in some European countries it does not mean denial of the right to self-determination and existence.
\end{abstract}

Keywords: PERSON, NATION, SLOVAKIA, FINLAND, ESTONIA, NORWAY

Problems still present in the Balkans, especially in cases of denial of the Macedonian national identity and the right to one's own history, impose the need for a broader comparative study of the processes of creation of some European nations or the instances where we may observe that some intellectuals belong to more nations. It is interesting to note that the belonging of a writer, poet to more nations does not necessarily have to lead to a dispute over the issue to which culture he or she belongs, as the case with our region is, where the denial of the right to self-determination is common. Czech historian Miroslav Hroch in his work for national revival among the smaller European nations gives interesting examples of how the idea of creating a nation arose, as well as of the participation of others in the creation of the idea of a nation.

Italy is now one of the most powerful European nations in every field. Nobody challenges the Italian identity. In the past there was no Italian nation, in the way we know it today. It is the result of the struggle of Italians for unification into a state in which the main opponent, for them, was the powerful Austrian Empire. Anyway, in 1861 
Italy was united and became a modern European state; however, there is an interesting point in this fight. In fact, shortly after the unification of the country, one of the main ideologists of Italian nationalism, which was in its infancy, Massimo d'Azeglio remarked: "We created Italy, now we need to create Italians." (Хобсбаум, 67) These words somehow coincide with the thought of one of the largest Polish statesmen Colonel Pilsudski, who is to be credited for the recurrence of Poland on the world map of countries and for strengthening its independence. He once said: "It is not the nation which generates the state rather it is the state which creates the nation." (ibidem). Balkan understanding of the nation and the state's role in its creation and strengthening is very different. The burden of the past and denying the rights of others is common. Does anyone today deny the existence of the Italian and the Polish nations, their tradition, culture and history? No, but we can notice from the above quotes that their leading figures recognise that nations are created by the existence of states.

Many nations in the world have people who they can share among themselves, as they have been important for their history, culture and tradition. An interesting example is the one with Adam Mickiewicz, the great Polish poet and patriot. He was born in what is now Belarus, wrote in Polish, but wrote also about Lithuania as part of the former Polish-Lithuanian Commonwealth. In his masterpiece Pan Tadeusz he wrote a poem that today every Polish and Lithuanian knows - "My Lithuania". Although he wrote his works in Polish, according to Go Koshino, he was considered a Lithuanian (Koshino, 119). In addition, because of the place of his birth, Navahrudak city, which is in present-day Belarus, he can be considered a Belarusian (Koshino, 120). Unlike the Balkans, Poles, Lithuanians and Belarusians who consider him as part of their culture do not argue among themselves over the question of who Adam Mickiewicz belongs to.

When it comes to the belonging of an intellectual to one of two or more nations we can mention Jan Barszczewski, a Polish writer born in what is now Belarus. His main work Nobleman Zawalnia, or Belarus in Fantastic Narratives, written in the period from 1844 to 1846, occupies an important place in the Belarusian literature of the 19th century, but is very rarely mentioned in Polish literature (ibidem). Barszczewski without a doubt belongs to the two Slavic nations - Poles and Belarusians.

Living together in the Polish - Lithuanian Commonwealth for centuries led to a very interesting phenomenon, which had an impact on the perception of the Lithuanians of themselves. The Poles dominated on the political and cultural levels. A rapid change of national consciousness among the nobility from Lithuanian into Polish occurred and the Polish language and culture became part of the identity of the ruling strata among Lithuanians (Xpox, 86). Lower layers of the Lithuanian society did not have developed national consciousness anyway. In this regard, Kavolis remarked: "The contrast between primitive peasant Lithuanian culture and Polish culture as the carrier of Western civilisation was so evident that many were ashamed of their Lithuanian origin, while Polish culture seemed only valuable for the person who went to school." (Merkys, 88). However, things changed over time. The collapse of the Polish state and its division between Russia, Prussia and the Habsburg monarchy had its impact on Lithuania. The bulk 
of this modern European country was given to Russia, and the smaller to Prussia, later Germany. Lithuanian culture became interesting for Polish and German researchers. According to Hroch, a number of Lithuanian folk songs were published between 1820 and 1860 (Xpox, 86). It probably had a major impact on the appearance or restoration of the Lithuanian identity. The first sign was the distancing of Lithuanian intellectuals from Polish cultural life (ibidem). Many who had once considered themselves to be Poles began to declare themselves as Lithuanians. A good indicator of this phenomenon was one of the biggest Lithuanian intellectuals at that time and one of the founders of Lithuanian nationalism Vincas Kudirka. This Lithuanian intellectual was completely polonised when he attended school in Marijampole. He behaved like a true Pole, he even used to run away from his parents in public, who acted as ordinary rural Lithuanians (Merkys, 86). Later, according to those who have studied his life, Kudirka considered himself both Polish and Lithuanian (ibidem). However, the emergence of the interest of Lithuanians in their past and their uniqueness could not remain without results in Kudirka, who himself faced with increasingly intensified attempts for russification of his country. Polish literature which he used had an impact on his views and understandings of Lithuania. This resulted in his complete transformation from Polish to Lithuanian orientation. In the magazine Varpas, in 1893, he published a column titled The bell of the homeland in which, inter alia, he wrote: "I once declared as Lithuanian and Polish, because history united Lithuanians and Poles. So admitting to be half Polish, I thought I would get rid of my second half of being Lithuanian" (Merkys, 89). He completely turned a new page in the past of his people. According to him, the role of history was of paramount significance for rebuilding the national identity of Lithuanians. From a Pole he became a Lithuanian, which he was. Does any Pole today contest the work of Kudirka, particularly his right to leave the nationality or identity to which he did not belong? No. Anyone can go back to his roots, without being subject to the present distortion of facts and denial of the right to self-determination.

The Czech-Slovak mix is a consequence of the long years of living together in the same state - the Habsburg monarchy and the Czechoslovak state, linguistic, cultural and religious similarities. In Slovakia, as the smaller nation and state in terms of Czechs, they are aware of the problem they could have over sharing the common persons or the persons who are important to both neighbouring and very similar nations. This can be observed in the book History of Slovak Literature by Peter Petro, who noted that when the Slovak writer wrote in Latin, no one would think that he was a Roman, but the problem appeared if the works were written in Czech, German or Hungarian (Koshino, 118). According to him, German, Hungarian, Jewish and all those authors who were not Slovaks were automatically excluded, even though they might have lived in Slovakia and wrote about Slovak themes or even used the Slovak language (ibidem). According to Koshino, it was difficult to discern who was a Slovak writer, especially at a time when people had a vague notion of national identity. However, a Slovak historian, J. Huchko, stressed that the criterion for patriotic literary action was the language, that is, whether the individual wrote in Czech or Slovak language (Xpox, 99). In fact Huchko, 
not without basis, set the criterion for the language. The Czech historian and theorist of nations and the nationalism of smaller nations, Miroslav Hroch, who wrote about the emergence of the Slovak national movement, observed: "The specific feature of Slovak cultural development was the fact that this development was closely intertwined with the Czech country. The Czech language was generally accepted in the Lutheran reformation in Slovakia, Slovak students were leaving for Prague and books in Czech were brought to Slovakia" (Xpox, 98). Therefore, it should not come as a surprise that some persons contributed to the tradition and culture of the two neighbouring close nations. Their origin does not mean that they have not been relevant to the history of the two nations. So, you can notice that Jan Kollar, Slovak by origin, an intellectual and advocate for Slavic unity, believed that all Slavs were part of a Slavic nation, speaking a Slavic language but divided into tribes who spoke different dialects (Maxwell, 160). He argued that the Slovaks and Czechs belonged to one tribe and opposed the creation of a separate Slovak language (Maxwell, 161). Kollar wrote his texts in archaic Czech language and tried to expand the use of this language in Slovakia (Bakke, 131). Today he is a very important person for Slovak culture and history.

When Slovaks, as part of the large Slavic community, are in question, we can also mention the example of a Slovak national song. The idea of all-Slavic cooperation and unification was very strong among many Slavic intellectuals during the 19th century. Today, we can notice that in the flags of many Slavic countries - Serbia, Croatia, Slovenia, Slovakia, Czech Republic, Russia and the former Yugoslav state - three colours dominate - white, blue and red, that is, the colours of Slavic unification, colours of PanSlavism. However, a song from the thirties of the 19th century is still today a synonym for Slavic unification. In 1834, Czech composer Samuel Tomashik created the song "Hey Slavs" (Maxwell, 161). However, as Maxwell noted, this song did not show an interest in the Czech specifics, but talked about "our Slavic language." (ibidem). Although the text of this song is in Czech, it later gave birth to a new song, this time in Slovak. In 1861, Andrew Radlinski wrote the song Hey Slovaks, making minimum changes to the text of Tomashik (Maxwell, 162). This song became the anthem of the Slovak state in the period from 1939 to 1945. It should be noted that this country was a satellite of the Tripartite Pact, which is an ally of Hitler's Germany. The same song, with the same text, was also the anthem of the former Yugoslav federation.

The Norwegian case is also interesting for our topic. Norway was an independent political entity in the Middle Ages, but following the personal union with Denmark, and later also with Sweden, it became a subordinate entity, particularly in respect to Denmark. So, in the era of the Reformation, the Danish dominance in politics was combined with the dominance in culture as well (Xpox, 33). The Norwegian language became almost extinct as a literary language and was completely replaced by Danish, which also became the language of educated people and the ruling class (ibidem). This conclusion of Hroch is very reminiscent of similar situations in the Balkans, where the language of educated people was Greek, regardless of the fact that many of them were not Greek by origin. In the first half of the 19th century in Norway, which was in a personal union 
with Sweden, the nationalist activist Henrik Vergeland wanted to create a Norwegian language which would distance the already danished Norwegian language and managed to create a language that is now known as Nynorsk (Хобсбаум, 81). He argued that the Norwegians had to be distinguished from other nations (Tomescu Baciu, 17). However, this language never became the Norwegian official language after the country became independent. According to Anderson, the Norwegians had long used the same written language with the Danes, with a different pronunciation, and nationalism emerged with the new Norwegian grammar published in 1848 and the dictionary published in 1850 (Андерсон, 111). But do the Danes today claim that Norwegians are Danes, or that Norwegian is a dialect of the Danish language? No.

Another Scandinavian nation is an interesting example for our topic. Today, Finland is one of the richest and most developed European countries. Nobody disputes the Finnish national identity which, unlike many identities, appeared relatively late. And this was not incidental. When you take a look at the Finnish history it becomes clear why the Finnish identity appeared later than today's European identities.

Finland, unlike other Scandinavian countries, did not have its own state in the Middle Ages. The present territory of the Finnish state until the early 19th century was part of Sweden, and then became part of Russia where it had a relatively high degree of autonomy. All this influenced the emergence of the Finnish national identity. Namely, according to Matveevskaya and Pogodin, the Finns defined themselves as minority (Matveevskaya, Pogodin, 100). Anderson observed, not without basis, that the awakened interest in the Finnish language and Finnish history was first expressed through texts written in Latin and Swedish in the late 18th century, and as late as in the 1820s it was more manifested in the local language (Андерсон, 111).

According to Hroch, the wave of national movement among Finns in cultural and linguistic terms was associated with Johann Wilhelm Snelman (Xpox, 62). He paid great attention to the language issue. In a letter to Topelius, he remarked: "If we were all Swedes based on the language, I would be happy. However, because now our eternal destiny is to live separately from the Swedes, something original must be developed among ourselves - some kind of our own share in world history, and it is civilisation ... Since all of us are not Swedes and we cannot become Swedes in modern conditions either, much less become French - then what is left? We have to become Finns ... Becoming Finns we must have a national language, a small corner in the world history, civilisation ... (Saukkonen, 3). Snelman clearly raised the issue of the language as a priority for the creation of the Finnish nation. It is interesting to note that the recognition of this Finnish intellectual, who had Swedish origin, of the need for the creation of the Finns today is not disputable for anyone. He is credited for the publication of the Act of 1863 of the Russian Emperor Alexander II to introduce the Finnish language as an official language within the local administration, along with Swedish (Singleton, 77).

Another Finnish intellectual Adolf Ivar Arvidsson advocated for the establishment of the Finnish national awareness. According to many he stated: "We are no more Swedes, we do not want to become Russians, so let us be Finns." (Matveevskaya, Pogo- 
din, 100). However, there are opinions that this was not in fact his statement, but words of Snelman as an expression of respect for the work and political activity of Arvidsson (ibidem). We will not engage into a discussion about whose this statement was, but we are free to conclude that these words best explain and confirm the right of self-determination of the nations, something that in our region is debatable even today. Snelman's words were logical given the Finnish past, as well as the moment in which he made this statement. Namely, following the entry of Finland as an autonomous province into the Russian Empire, there was an increasing influence of nationalist ideas from the German countries. Finns did not want to be Russians and could not return under Swedish cultural dominance; thus, the only way for them to become a nation was the integration of educated people and ordinary people (Lyytikåinen, 7). However, it must be noted that due to tradition the most educated were those who had Swedish origin and spoke Swedish.

One of the most prominent intellectuals in the 19th century in Finland, who contributed a lot to the Finnish culture, was Zacharias Topelius. And he, like other prominent Finnish reformists created in Swedish. Topelius, devoted great attention to the Finnish past in his works (Hatavara, 80). His work in Swedish does not diminish the contribution to Finnish history, culture and the development of the Finnish identity. Here we should mention that Topelius foresaw the decreasing use of the Swedish language in Finland.

Czech Slavist Ivan Dorovski, famous for his views on the belonging of authors to more cultures, noted that the prominent Finnish reformer Johann Ludwig Runenberg, the author of the Finnish national anthem, was a typical example of a writer belonging to two literatures - Finnish and Swedish (Доровски, 88). In his works he wrote about the Finns, but in the Swedish language. Therefore, some authors rightly thought that "he was the first Swedish writer who identified his work with the fate of the Finnish people." (ibidem).

Hobsbawm, referring to the work of Finnish intellectuals, noted that the Finnish Literary Society, founded in 1831, was founded by Swedes, and its documentation was kept in Swedish. Also, all the texts of the ideologist of the Finnish cultural nationalism Snelman were written in Swedish (Хобсбаум, 150). In fact, in Finland, the members of the intelligentsia which used the Swedish language, underwent a linguistic conversion inspired by the ideas of the German philosopher Herder about the importance of the language in the creation of the nation (Kaljundi, Laanes, Pikkanen, 29). This fact does not diminish the significance of the Finnish cultural nationalism. Today Swedes do not claim that Finns do not exist, nor that Finnish history is essentially Swedish, although Finland was part of Sweden and the Swedish influence on Finnish culture and tradition cannot be denied. It is known that in Finland, in the second half of the 19th century, there was certain class struggle between the lower classes of Finns, represented by those who advocated a single nation with Finnish as its mother tongue and upper classes, who were part of the Swedish minority, represented by those who considered that there 
were two nations in the country, and therefore two languages (Хобсбаум, 154). Today, in the Åland Islands, which are part of Finland, Swedish is the official language.

Estonia also used an interesting method in the creation of a national identity that today is not controversial to anyone. Hobsbawm, when it comes to Estonians, noted that the Estonian peasants did not manifest an interest in being seen as an ethnic-linguistic group. According to him, the word Estonian entered into use during the sixties of the 19th century (Хобсбаум, 72). Before that, they called themselves maarahvi, meaning "Polish people". Something similar happened in Ottoman Macedonia and in other parts of the Balkans, where national consciousness was not developed, and often inhabitants were considered "ours", "locals" and so on. Hobsbawm noted that the word Sachs in Estonia was a name for a master, and the very word German was of secondary importance (ibidem). The emergence of Estonian nationalism and the identity were closely linked to the Baltic German cultural history, although the impact of the German upper class in Estonia was strongly criticised by the same circles (Kaljundi, Laanes, Pikkanen, 29). Here, we should mention the great influence of the so-called estofili, who were mainly Baltic Germans born in Estonia. In this respect, we should mention Johann Heinrich Rosenplanter, Kristian Jaak Peterson, Otto Wilhelm Masing, Arnold Friedrich Johann Knupfer, Johann Friedrich Heller and others (Erelt, 380). Rosenplanter founded a journal for the study of the Estonian language. Baltic Germans had a big share in the establishment of the Estonian Learned Society (ibidem). However, as Hobsbawm noted earlier, their engagement in the national revival of the Estonians did not mean that the latter would not fight against the German cultural influence in their country.

Finally, we can conclude that the process of creation of nations was complex and different in various parts of the world. However, we can also notice many similarities, especially when it comes to the creation of smaller nations. The role of others in their revival is great, and sometimes, as the case with the Finns and the Estonians is, it may have been decisive. Common history and the belonging of some intellectuals to several nations is not the case just in the Balkans; it was also seen in Central and Eastern Europe. A difference, however, exists. Shared past in the Balkans is accepted with fear or is the basis for denying the right to existence and one's own past. The belonging of some authors to two or more nations is not solely a Balkan phenomenon, but it is only in our region causing problems and accusations of stealing historical and cultural heritage. The view and research of the development of the other smaller nations show that our Balkan, and especially the Macedonian, case is not unique. The lessons are great. 


\section{References}

Андерсон, Бенедик. (1998). Замислени заеgници. Скопје: Култура.

Bakke, Elisabeth. (1999). Doomed or failure? The Czechoslovak nation project and the Slovak autonomist reaction 1918-38. PhD Dissertation, Department of Political Science, Faculty of Social Sciences, University of Oslo.

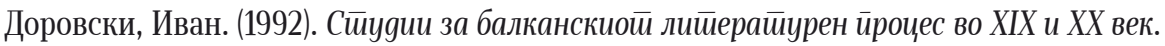
Скопје: МАНУ.

Erelt, Mati. (2003). Estonian language. Tallinn: Estonian Academy Publishers.

Kaljundi Linda, Laanes Eneken, Pikkanen Ilona. (2015). Historical fiction, cultural memory and nation building in Finland and Estonia. in: Linda Kaljundi, Eneken Laanes, Ilona Pikkanen (ed.). Novels, histories, novel nations. Historical fiction and cultural memory In Finland and Estonia. Studia Fennica, Historia, Helsinki.

Go Koshino. (2016). Sharing writers for a small nations: Belarusian - Jewish - Russian writer Grigory Reles. Slavic Eurasian studies, 30.

Lyytikåinen, Pirjo. (ed.). (2003). Changing scenes. Encounters between European ana Finnish fin de siècle. Finnish Literature Society, Helsinki.

Matveevskaya, A.S., Pogodin S.N. (2016). Establishment of Finnish identity. Весйник СПбГУ, сер. 17, в. 3.

Maxwell, Akexander. (2006). "Hey Slovaks, where is my home?" Slovak lyrics for non Slovak national songs. Philologica Jassyensia, an. II, n. 1.

Merkys, Vytautas. (2000). Vincas Kudirka's concept of Lithuania. Lithuanian Historical studies, 5.

Singelton, Fred. (2003). A short history of Finland. Cambridge: Cambridge University Press.

Saukkonen, Pasi. (2012). The Finnish paradox: Language and politics in Finland, RECODE working papers series, n. 5 .

Tomescu Baciu, Sanda. Norwegian distinctiveness. A cultural construction. Studia UBB Philologia, LVII/2, 2012

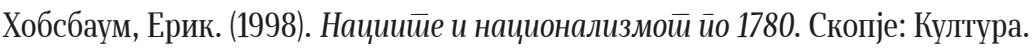

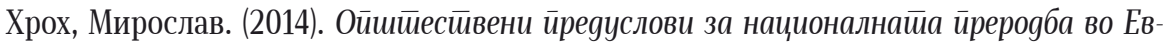

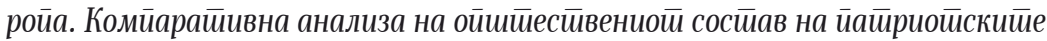

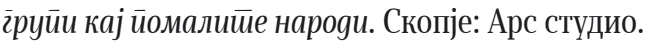

